\title{
Bioactive Metabolites Produced by Penicillium sp.1 and sp.2, Two Endophytes Associated with Alibertia macrophylla (Rubiaceae)
}

Camila M. Oliveira ${ }^{\text {a }}$, Geraldo H. Silva ${ }^{\mathrm{b}}$, Luis O. Regasini ${ }^{\mathrm{a}}$, Lisinéia M. Zanardi ${ }^{\mathrm{a}}$, Alana H. Evangelista ${ }^{\mathrm{a}}$, Maria C. M. Young ${ }^{\mathrm{c}}$, Vanderlan S. Bolzani ${ }^{\mathrm{a}}$, and Angela R. Araujo ${ }^{\mathrm{a}, *}$

a NuBBE - Núcleo de Bioensaios, Biossíntese e Ecofisiologia de Produtos Naturais, Departamento de Química Orgânica, Instituto de Química, Universidade Estadual Paulista, Rua Professor Francisco Degni, SN, Bairro Quitandinha, 14800-900 Araraquara, São Paulo, Brazil. Fax +55-16-33 22 79 32. E-mail: araujoar@iq.unesp.br

b Universidade Federal de Sergipe, Av. Vereador Olimpio Grande, SN, 49500-000 Itabaiana, Sergipe, Brazil

c Seção de Fisiologia e Bioquímica de Plantas, Instituto de Botânica, Av. Miguel Stéfano 3687, 04301-902 São Paulo, São Paulo, Brazil

* Author for correspondence and reprint requests

Z. Naturforsch. 64c, 824-830 (2009); received June 29, 2009

In the course of our continuous search for bioactive metabolites from endophytic fungi living in plants from the Brazilian flora, leaves of Alibertia macrophylla (Rubiaceae) were submitted to isolation of endophytes, and two species of Penicillium were isolated. The acetonitrile fraction obtained in corn from a culture of Penicillium sp.1 afforded orcinol (1). On the other hand, Penicillium sp.1 cultivated in potato-dextrose-broth furnished two different compounds, cyclo-(L-Pro-L-Val) (2) and uracil (3). The chromatographic fractionation of the acetonitrile fraction obtained from Penicillium sp.2 led to three dihydroisocoumarins, 4-hydroxymellein (4), 8-methoxymellein (5) and 5-hydroxymellein (6). Compounds 5 and $\mathbf{6}$ were obtained from the Penicillium genus for the first time. Additionally, metabolites 1-6 were evaluated for their antifungal and acetylcholinesterase (AChE) inhibitory activities. The most active compounds $\mathbf{1}$ and $\mathbf{4}$ exhibited detection limits of 5.00 and $10.0 \mu \mathrm{g}$ against Cladosporium cladosporioides and C. sphaerospermum, respectively. Compound $\mathbf{2}$ showed a detection limit of $10.0 \mu \mathrm{g}$, displaying potent AChE inhibitory activity.

Key words: Penicillium, Alibertia macrophylla, Endophytic Fungi, Acetylcholinesterase

\section{Introduction}

Terrestrial-derived microfungi have been the sources of several novel and pharmacologically active compounds over decades (Hormazabal et al., 2005; Schmeda-Hirschmann et al., 2008; Takahashi and Lucas, 2008). In this context, endophytes belonging to the Penicillium genus have been recognized as a rich source of bioactive secondary metabolites (Fill et al., 2007). Recent examples include the anticancer berkelic acid from Penicillium sp., polyketides with HIV-integrase inhibitory activity from $P$. chrysogenum and the insecticidal paraherquamides $\mathrm{H}$ and I from P. cluniae (Singh, 2003; Stierle et al., 2006).

As part of our interest for bioactive metabolites from endophytes associated with Brazilian plants (Cafêu et al., 2005; Inácio et al., 2006; Silva et al., 2006; Teles et al., 2006), Alibertia macrophylla (Rubiaceae) was selected for our study, due to the fact that this species accumulates a series of bioactive compounds (Bolzani et al., 1991; Silva et al., 2007).

Thus, the major aim of the current study was to identify potential bioactive compounds from Penicillium sp.1 and Penicillium sp.2, two endophytes associated with $A$. macrophylla leaves, by using antifungal and acetylcholinesterase inhibitory assays.

\section{Material and Methods}

\section{General}

${ }^{1} \mathrm{H}$ NMR (500 MHz), ${ }^{13} \mathrm{C}$ NMR (126 MHz), $g \mathrm{HMBC}, g \mathrm{HMQC}$ and $g \mathrm{COSY}$ experiments were recorded on a VARIAN DRX-500 spectrometer, using the solvents as internal standard. Mass spectra were measured on a Q-TOF Micromass spectrometer in the ESI mode using $\mathrm{MeOH} / \mathrm{H}_{2} \mathrm{O}$ $(1: 1)$ as solvent (cone voltage $25 \mathrm{~V}$ ). TLC was 
performed using Merck silica gel 60 (230 mesh) and precoated silica gel $60 \mathrm{PF}_{254}$ plates. Spots on TLC plates were visualized under UV light and by spraying with anisaldehyde $/ \mathrm{H}_{2} \mathrm{SO}_{4}$ reagent followed by heating at $120^{\circ} \mathrm{C}$. Preparative HPLC was performed on a Varian Prep-Star 400 system using a Phenomenex C-18 preparative column $(250 \mathrm{~mm} \times 21.2 \mathrm{~mm})$. Analytical HPLC was performed on a Varian Pro Star 230 instrument using a Phenomenex C-18 column $(250 \mathrm{~mm} \times 4.6 \mathrm{~mm})$. Column chromatography (CC) was performed over reversed-phase silica gel 230-400 mesh (Merck).

\section{Plant material}

Authenticated Alibertia macrophylla K. Schum. (Rubiaceae) was collected in Estação Ecológica Experimental de Mogi-Guaçu, Fazenda Campininha, Mogi-Guaçu, São Paulo, Brazil, in November 2003. The botanical identification was made by Ph.D. Maria Cláudia Marx Young (Institute of Botany, São Paulo, Brazil), and a voucher specimen was deposited at the Herbarium of the Botanic Garden of São Paulo, Brazil (voucher no. SP 370915).

\section{Isolation and identification of the endophytes}

For isolation of the endophytic fungi, adult and healthy leaves of $A$. macrophylla were selected and submitted to surface sterilization. They were first washed with water and soap, and then immersed in an $1 \%$ aqueous sodium hypochlorite solution for $5 \mathrm{~min}$ and $70 \%$ aqueous ethanol for $1 \mathrm{~min}$. A second washing with water and soap was performed and finally the leaves were immersed in sterile water for $10 \mathrm{~min}$. Sterilized leaves were cut into $2 \times 2 \mathrm{~cm}$ pieces and deposited on a Petri dish containing PDA (potato-dextrose-agar) and anthramicine sulfate $(50 \mathrm{mg} / \mathrm{mL})$ with approx. 3 to 4 pieces on each dish (Silva et al., 2006).

The endophytic fungi were identified according to the characteristics of morphology of the culture and spores, mechanism of spore production, and molecular taxonomy according to a modification of the rapid preparation of DNA from filamentous fungi (Raeder and Broda, 1985). The fungi were identified by Ph.D. Derlene Attili de Angelis (CPQBA-UNICAMP - Centro Pluridisciplinar de Pesquisas Químicas, Biológicas e Agrícolas, Campinas, Brazil) and deposited in our collection with culture numbers 05070032-C and
05-070032-A for Penicillium sp.1 and Penicillium sp.2, respectively.

\section{Preparation of the crude extract in corn and potato-dextrose-broth of Penicillium sp.1}

The cultivation in corn was accomplished in 9 Erlenmeyer flasks $(500 \mathrm{~mL})$ each containing as medium $90 \mathrm{~g}$ of corn and $75 \mathrm{~mL}$ of water. The media were autoclaved four times (four consecutive days) at $121^{\circ} \mathrm{C}$ for $40 \mathrm{~min}$. After cool, the media were inoculated with the endophyte and incubated at $25^{\circ} \mathrm{C}$ in static mode for $21 \mathrm{~d}$. After the incubation period, the solid cultures were ground and extracted with $\mathrm{MeOH}(6 \times 250 \mathrm{~mL})$; after that the solvent was evaporated, providing the crude $\mathrm{MeOH}$ extract $(10.6 \mathrm{~g})$. The methanol extract was dissolved in water and then subjected to liquid-liquid partition with EtOAc. The EtOAc fraction was suspended in acetonitrile and partitioned with hexane. Evaporation of the organic phase resulted in the crude acetonitrile extract (804 mg).

The fungus was cultivated using potato-dextrose-broth (PDB) as culture medium $(4.0 \mathrm{~g}$ of potato extract, $20.0 \mathrm{~g}$ dextrose $/ \mathrm{L}_{2} \mathrm{O}$ ). For the PDB, 20 Erlenmeyer flasks $(500 \mathrm{~mL})$ were used, each containing $100 \mathrm{mg}$ of potato extract, $5.0 \mathrm{~g}$ dextrose and $250 \mathrm{~mL}$ distilled water, which were autoclaved at $125^{\circ} \mathrm{C}$ for $15 \mathrm{~min}$. Approx. 10 small pieces $\left(1 \mathrm{~cm}^{2}\right)$ of PDA medium from the Petri dish containing biomass of Penicillium sp.1 were inoculated into each flask, and the flasks were sealed with cotton to permit aerobic growth. After incubation for $28 \mathrm{~d}$ at $25^{\circ} \mathrm{C}$ on rotatory shakers at $150 \mathrm{rpm}$, the mycelia biomass accumulated in the flasks was separated from the aqueous medium by filtration, and the filtrate was partitioned with EtOAc $(3 \times 2.5 \mathrm{~L})$. Collection and evaporation of the organic phase under reduced pressure yielded a brown, solid residue $(507 \mathrm{mg})$.

\section{Preparation of the crude extract in corn of Penicillium sp.2}

The cultivation in corn was accomplished in 9 Erlenmeyer flasks $(500 \mathrm{~mL})$ each containing as medium $90 \mathrm{~g}$ of corn and $75 \mathrm{~mL}$ of water. The media were autoclaved four times (four consecutive days) at $121^{\circ} \mathrm{C}$ for $40 \mathrm{~min}$. After cooling, the media were inoculated with the endophyte and incubated at $25^{\circ} \mathrm{C}$ in static mode for $21 \mathrm{~d}$. After the incubation period, the solid cultures were 
ground and extracted with EtOAc $(6 \times 250 \mathrm{~mL})$; after that the solvent was evaporated, providing the crude EtOAc extract $(15.0 \mathrm{~g})$. The EtOAc extract was dissolved in acetonitrile and then subjected to liquid-liquid partition with hexane. The acetonitrile fraction was evaporated resulting in the crude acetonitrile extract $(6.0 \mathrm{~g})$.

\section{Isolation and identification of compounds $\mathbf{1}-\mathbf{6}$}

The crude acetonitrile fraction obtained in corn of Penicillium sp.1 (804 mg) was fractionated by $\mathrm{CC}$ using silica gel $\mathrm{C} 18$ eluted with a $\mathrm{H}_{2} \mathrm{O} / \mathrm{ac}-$ etonitrile gradient $(10-100 \%$ acetonitrile) affording 10 fractions (A-J). Fraction D (13.1 mg) afforded compound 1. The crude EtOAc extract obtained in PDB of Penicillium sp.1 (507 mg) was fractionated by $\mathrm{CC}$ using silica gel $\mathrm{C} 18$ eluted with a $\mathrm{H}_{2} \mathrm{O}$ /acetonitrile gradient $(10-100 \%$ acetonitrile) affording 5 fractions $(\mathrm{K}-\mathrm{O})$. Fraction $\mathrm{C}(30.5 \mathrm{mg})$, after recrystallization with $\mathrm{MeOH}$, led to compound 2 (4.5 mg). Fraction L (40.2 mg) was further purified using RP-HPLC $[\lambda=254 \mathrm{~nm}$, $12.0 \mathrm{~mL} / \mathrm{min}, \mathrm{H}_{2} \mathrm{O} /$ acetonitrile $\left.(9: 1,40 \mathrm{~min})\right]$ and supplied compound $\mathbf{3}\left(12.4 \mathrm{mg}, R_{\mathrm{t}}=3 \mathrm{~min}\right)$.

The crude acetonitrile fraction obtained in corn of Penicillium sp.2 $(6.0 \mathrm{~g})$ was fractionated by CC using silica gel $\mathrm{C} 18$ eluted with a $\mathrm{H}_{2} \mathrm{O} / \mathrm{MeOH}$ gradient $(5-100 \% \mathrm{MeOH})$ affording 16 fractions (Fr1-Fr16). Fraction Fr2 (218.0 mg) was further purified using RP-HPLC $[\lambda=254 \mathrm{~nm}, 10.0 \mathrm{~mL} /$ min, $\mathrm{H}_{2} \mathrm{O}$ /acetonitrile $\left.(8: 2,80 \mathrm{~min})\right]$ leading to compounds 4 (3.4 mg, $\left.R_{\mathrm{t}}=24.5 \mathrm{~min}\right), 5(5.3 \mathrm{mg}$, $\left.R_{\mathrm{t}}=31.1 \mathrm{~min}\right)$ and $6\left(6.3 \mathrm{mg}, R_{\mathrm{t}}=62.3 \mathrm{~min}\right)$.

Orcinol (1): ${ }^{1} \mathrm{H}$ NMR (500 MHz, DMSO- $\left.d_{6}\right)$ : $\delta=8.97(2 \mathrm{H}$, brs, $1-\mathrm{OH}$ and $5-\mathrm{OH}), 6.01(2 \mathrm{H}, d$, $J=2.0 \mathrm{~Hz}, \mathrm{H}-2$ and $\mathrm{H}-4), 5.99(1 \mathrm{H}, d, J=2.0 \mathrm{~Hz}$, $\mathrm{H}-6), 2.43(3 \mathrm{H}, s, \mathrm{H}-7) .-{ }^{13} \mathrm{C}$ NMR $(126 \mathrm{MHz}$, DMSO- $\left.d_{6}\right): \delta=158.1$ (C-1, C-5), 138.9 (C-3), 106.9 (C-2, C-4), 99.7 (C-6), 21.1 (C-7).

Cyclo(L-Pro-L-Val) (2): ${ }^{1} \mathrm{H}$ NMR $(500 \mathrm{MHz}$, DMSO- $\left.d_{6}\right): \delta=7.92(1 \mathrm{H}$, brs, $\mathrm{H}-8), 4.12(1 \mathrm{H}, t$, $J=7.5 \mathrm{~Hz}, \mathrm{H}-6), 3.92(1 \mathrm{H}$, brs, $\mathrm{H}-9), 3.40(2 \mathrm{H}, m$, $\mathrm{H}-3), 2.35(1 \mathrm{H}$, dsept, $J=2.5,6.5 \mathrm{~Hz}, \mathrm{H}-10), 2.13$ $(2 \mathrm{H}, m, \mathrm{H}-5), 1.78(2 \mathrm{H}, m, \mathrm{H}-4), 1.02(3 \mathrm{H}, d, J=$ $6.5 \mathrm{~Hz}, \mathrm{H}-12), 0.86(3 \mathrm{H}, d, J=6.5 \mathrm{~Hz}, \mathrm{H}-11)$. ${ }^{13} \mathrm{C}$ NMR (126 MHz, DMSO- $\left.d_{6}\right): \delta=170.2(\mathrm{C}-7)$, 165.2 (C-1), 59.5 (C-9), 58.2 (C-6), 44.6 (C-3), 27.7 (C-5, C-10), 22.0 (C-4), 16.4 (C-11), 18.3 (C-12).

Uracil (3): ${ }^{1} \mathrm{H}$ NMR (500 MHz, DMSO- $\left.d_{6}\right)$ : $\delta=7.38(1 \mathrm{H}, d, J=8.0 \mathrm{~Hz}, \mathrm{H}-6), 5.41(1 \mathrm{H}, d, J=$
8.0 Hz, H-5). $-{ }^{13} \mathrm{C}$ NMR (126 MHz, DMSO- $\left.d_{6}\right)$ : $\delta=164.4$ (C-4), 151.9 (C-2), 142.9 (C-6), 99.9 (C$5)$.

4-Hydroxymellein (4): ${ }^{1} \mathrm{H}$ NMR $(500 \mathrm{MHz}$, DMSO- $\left.d_{6}\right): \delta=11.0(1 \mathrm{H}, b r s, 8-\mathrm{OH}), 7.45(1 \mathrm{H}$, $d d, J=7.5,8.5 \mathrm{~Hz}, \mathrm{H}-6), 6.96(1 \mathrm{H}, d, J=7.5 \mathrm{~Hz}$, $\mathrm{H}-7), 6.86(1 \mathrm{H}, d, J=7.5 \mathrm{~Hz}, \mathrm{H}-5), 4.63(1 \mathrm{H}, d q$, $J=6.5,2.0 \mathrm{~Hz}, \mathrm{H}-3), 4.50(1 \mathrm{H}, d, J=2.0 \mathrm{~Hz}, \mathrm{H}-4)$, $1.90(1 \mathrm{H}, b r 4-\mathrm{OH}), 1.51(3 \mathrm{H}, d, J=6.5 \mathrm{~Hz}, \mathrm{H}-9)$. $-{ }^{13} \mathrm{C}$ NMR $\left(126 \mathrm{MHz}, \mathrm{DMSO}-d_{6}\right): \delta=169.1(\mathrm{C}-$ 1), 162.1 (C-8), 140.5 (C-4a), 136.7 (C-6), 118.5 (C-5), 118.2 (C-7), 106.8 (C-8a), 78.1 (C-3), 67.2 (C-4), 16.0 (C-9).

8-Methoxymellein (5): ${ }^{1} \mathrm{H}$ NMR (500 MHz, DMSO- $\left.d_{6}\right): \delta=7.35(1 \mathrm{H}, t, J=8.0 \mathrm{~Hz}, \mathrm{H}-6), 6.83(1 \mathrm{H}$, $d, J=8.0 \mathrm{~Hz}, \mathrm{H}-7), 6.71(1 \mathrm{H}, d, J=8.0 \mathrm{~Hz}, \mathrm{H}-5)$, $4.48(1 \mathrm{H}, m, \mathrm{H}-3), 3.88(3 \mathrm{H}, s, \mathrm{H}-10), 2.80(2 \mathrm{H}, m$, $\mathrm{H}-4), 1.40(3 \mathrm{H}, d, J=6.0 \mathrm{~Hz}, \mathrm{H}-9) .-{ }^{13} \mathrm{C} \mathrm{NMR}$ $\left(126 \mathrm{MHz}, \mathrm{DMSO}-d_{6}\right): \delta=162.5(\mathrm{C}-1), 161.2(\mathrm{C}-$ 8), 141.8 (C-4a), 134.3 (C-6), 119.1 (C-5), 113.0 (C-8a), 110.9 (C-7), 74.0 (C-3), 56.1 (C-10), 36.1 (C-4), 20.6 (C-9).

5-Hydroxymellein (6): ${ }^{1} \mathrm{H}$ NMR $(500 \mathrm{MHz}$, DMSO- $\left.d_{6}\right): \delta=10.5(1 \mathrm{H}$, brs, $8-\mathrm{OH}), 6.92(1 \mathrm{H}, d$, $J=9.0 \mathrm{~Hz}, \mathrm{H}-6), 6.73(1 \mathrm{H}, d, J=9.0 \mathrm{~Hz}, \mathrm{H}-7), 4.63$ $(1 \mathrm{H}, m, \mathrm{H}-3), 3.08(2 \mathrm{H}, d d, J=3.5,16.5 \mathrm{~Hz}, \mathrm{H}-4)$, $2.62(2 \mathrm{H}, d d, J=11.5,16.5 \mathrm{~Hz}, \mathrm{H}-4), 1.49(1 \mathrm{H}, d$, $J=6.5 \mathrm{~Hz}, \mathrm{H}-9) .-{ }^{13} \mathrm{C}$ NMR $(126 \mathrm{MHz}$, DMSO$\left.d_{6}\right): \delta=161.5(\mathrm{C}-1), 156.5(\mathrm{C}-8), 143.0(\mathrm{C}-5), 125.0$ (C-4a), 124.0 (C-6), 116.0 (C-7), 108.5 (C-8a), 76.0 (C-3), 28.0 (C-4), 21.0 (C-9).

\section{Antifungal activity}

Cladosporium cladosporioides (Fresen) de Vries SPC 140 and C. sphaerospermum (Perzig) SPC 491 were used in the antifungal assay. They have been maintained at the Institute of Botany, São Paulo, Brazil. Compounds 1-6 were applied on precoated silica gel TLC plates using a solution $(10 \mu \mathrm{L})$ containing 100, 50.0, 25.0, 10.0, 5.00 and $1.00 \mu \mathrm{g}$ of each. After eluting with adequate solvent they were sprayed with the fungi (Rahalison et al., 1991). Nystatin was adopted as positive control.

\section{Acetylcholinesterase (AChE) inhibitory activity}

Acetylcholinesterase (1000 U) was dissolved in $150 \mathrm{~mL}$ of $0.05 \mathrm{M}$ Tris-hydrochloric acid buffer at $\mathrm{pH} 7.8$; bovine serum albumin $(150 \mathrm{mg})$ was add- 
ed to the solution in order to stabilize the enzyme during the biochemical assay. The stock solution was kept at $4{ }^{\circ} \mathrm{C}$. TLC plates were eluted with an appropriate solvent (acetone or isopropanol), in order to wash them, and were thoroughly dried just before use. After migration of the sample in a suitable solvent (or direct deposition of sample), the TLC plate was dried for complete removal of the solvent. The plate was then sprayed with enzyme stock solution and thoroughly dried again. For incubation of the enzyme, the plate was laid flat on plastic plugs in a plastic tank containing a little bit of water; by this means, water did not come directly into contact with the plate but the atmosphere was kept humid. The cover was placed on the tank and incubation was performed at $37^{\circ} \mathrm{C}$ for $20 \mathrm{~min}$. For detection of the AChE inhibitory activity, solutions of 1-naphthyl acetate $(250 \mathrm{mg})$ in EtOH $(100 \mathrm{~mL})$ and of Fast Blue B salt $(400 \mathrm{mg})$ in distilled water $(160 \mathrm{~mL})$ were prepared immediately before use. After incubation of the TLC plate, $10 \mathrm{~mL}$ of the 1-naphthyl acetate solution and $40 \mathrm{~mL}$ of the Fast Blue $B$ salt solution were mixed and sprayed onto the plate to give a purple colouration after 1-2 min. Galanthamine was employed as positive control (Marston et al., 2002).

\section{Results and Discussion}

The molecular structures of all isolates (Fig. 1) were confirmed by the MS and NMR data as shown below. Assignments were based on 2DNMR experiments including $g \mathrm{COSY}, g \mathrm{HMQC}$, and $g \mathrm{HMBC}$.

Compound 1 was isolated as a brown amorphous powder and its ESI mass data suggested the molecular formula $\mathrm{C}_{7} \mathrm{H}_{8} \mathrm{O}_{2}\left([\mathrm{M}-\mathrm{H}]^{-}\right.$at $\mathrm{m} / z$ 123). The ${ }^{1} \mathrm{H}$ NMR spectrum of $\mathbf{1}$ showed two aromatic signals, $\delta_{\mathrm{H}} 5.99(d, J=2.0 \mathrm{~Hz}, 1 \mathrm{H}, \mathrm{H}-6)$ and $\delta_{\mathrm{H}}$ $6.01(d, J=2.0 \mathrm{~Hz}, 2 \mathrm{H}, \mathrm{H}-2$ and $\mathrm{H}-4)$ suggesting a trisubstituted aromatic ring. The ${ }^{13} \mathrm{C}$ NMR and DEPT $135^{\circ}$ spectra showed five signals, assigned to one oxygenated aromatic groups at $\delta_{\mathrm{C}} 158.1$ (C-1 and C-5), two methines attributed to signals at $\delta_{\mathrm{C}} 99.7(\mathrm{C}-6)$ and $\delta_{\mathrm{C}} 106.9(\mathrm{C}-2$ and C-4) and one methyl group at $\delta_{\mathrm{C}} 21.1(\mathrm{C}-7)$. The position of the methyl substituent at position $\mathrm{C}-3$ was attributed on the basis on the $\mathrm{HHMBC}$ experiment, which indicates a correlation of $\delta_{\mathrm{H}} 2.43(\mathrm{H}-7)$ with $\delta_{\mathrm{C}} 138.9(\mathrm{C}-3)$ and $\delta_{\mathrm{C}} 106.9(\mathrm{C}-2$ and $\mathrm{C}-4)$. This data suggests that $\mathbf{1}$ is orcinol (Monde, 1998).
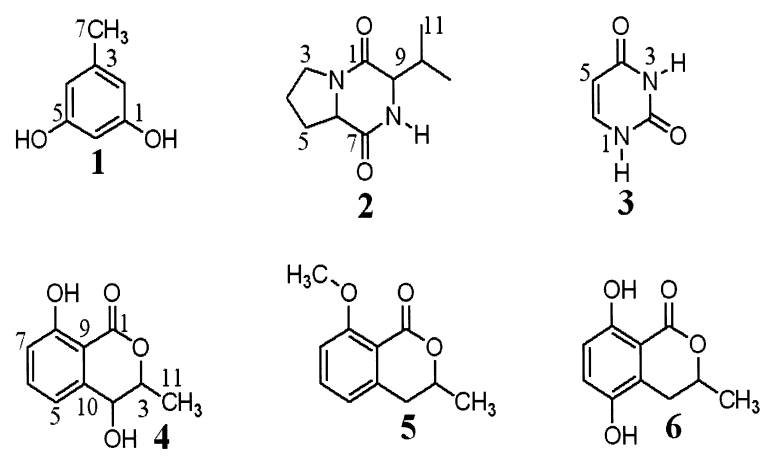

Fig. 1. Chemical structures of compounds $\mathbf{1 - 6}$ isolated from Penicillium sp.1 and Penicillium sp.2.

Compound $\mathbf{2}$ was isolated as a white amorphous solid and its ESI mass data indicated the molecular formula $\mathrm{C}_{10} \mathrm{H}_{16} \mathrm{~N}_{2} \mathrm{O}_{2}\left([\mathrm{M}+\mathrm{H}]^{+}\right.$at $\mathrm{m} / z$ 197). The ${ }^{1} \mathrm{H}$ NMR spectrum of $\mathbf{2}$ showed signals at $\delta_{\mathrm{H}} 0.86(d, J=6.5 \mathrm{~Hz}, 3 \mathrm{H}, \mathrm{H}-11), \delta_{\mathrm{H}} 1.02(d$, $J=6.5 \mathrm{~Hz}, 3 \mathrm{H}, \mathrm{H}-12), \delta_{\mathrm{H}} 4.12(t, J=7.5 \mathrm{~Hz}, 1 \mathrm{H}$, $\mathrm{H}-6)$, and $\delta_{\mathrm{H}} 3.92($ brs $, 1 \mathrm{H}, \mathrm{H}-9)$. Also, three multiplets at $\delta_{\mathrm{H}} 3.40(2 \mathrm{H}, \mathrm{H}-3), 1.78(2 \mathrm{H}, \mathrm{H}-4)$, and $2.13(2 \mathrm{H}, \mathrm{H}-5)$ were observed. Analysis of the ${ }^{13} \mathrm{C}$ NMR spectrum indicated two methyl groups, three methylene carbon atoms and three methine carbon atoms. The signals at $\delta_{\mathrm{C}} 170.2$ and $\delta_{\mathrm{C}} 165.2$ were attributed to two amide carbonyl groups at C-7 and C-1, respectively, and ${ }^{1} \mathrm{H}$ NMR signals of an amino acid suggested that $\mathbf{2}$ belongs to the diketopiperazine class. The $g \mathrm{HMBC}$ cross-peaks between the signal for $\mathrm{C}-1$ and the signals for $\mathrm{H}-3$, $\mathrm{H}-6, \mathrm{H}-9$, and $\mathrm{H}-10$, as well as the signal for $\mathrm{C}-7$ and the signals for $\mathrm{H}-5, \mathrm{H}-6$, and $\mathrm{H}-9$ confirmed that 2 was biosynthesized by condensation of the amino acids proline and valine. The interpretation of these results combined with comparison with literature data (Furtado et al., 2005) suggest that diketopiperazine $\mathbf{2}$ is cyclo-(L-Pro-L-Val).

Compound $\mathbf{3}$ was isolated as yellow amorphous solid and its ESI mass data suggested the molecular formula $\mathrm{C}_{4} \mathrm{H}_{4} \mathrm{~N}_{2} \mathrm{O}_{2}\left([\mathrm{M}-\mathrm{H}]^{-}\right.$at $\mathrm{m} / z$ 111). The ${ }^{1} \mathrm{H}$ NMR spectrum of $\mathbf{3}$ appeared to be relatively simple, exhibiting two doublets at $\delta_{\mathrm{H}} 5.41(d, J=$ $8.0 \mathrm{~Hz}, 1 \mathrm{H}, \mathrm{H}-5)$ and $\delta_{\mathrm{H}} 7.38(d, J=8.0 \mathrm{~Hz}, 1 \mathrm{H}$, $\mathrm{H}-6)$. The ${ }^{13} \mathrm{C}$ NMR spectrum showed only four signals, for two carbonyl groups $\left[\delta_{\mathrm{C}} 151.9(\mathrm{C}-2)\right.$ and $\left.\delta_{\mathrm{C}} 164.4(\mathrm{C}-4)\right]$ and two methines $\left[\delta_{\mathrm{C}} 99.9(\mathrm{C}-\right.$ $5)$ and $\left.\delta_{\mathrm{C}} 142.9(\mathrm{C}-6)\right]$. These data indicate that 3 is uracil (Schindler, 1998; Martin et al., 2007). 
Compound 4 was isolated as a white amorphous solid and its ESI mass data indicated the molecular formula $\mathrm{C}_{10} \mathrm{H}_{10} \mathrm{O}_{4}\left([\mathrm{M}+\mathrm{Na}]^{+}\right.$at $m / z$ 217). The ${ }^{1} \mathrm{H}$ NMR spectrum showed doublets for three aromatic protons at $\delta_{\mathrm{H}} 6.86(d, J=7.5 \mathrm{~Hz}, 1 \mathrm{H}, \mathrm{H}-5)$, $\delta_{\mathrm{H}} 6.96(d, J=7.5 \mathrm{~Hz}, 1 \mathrm{H}, \mathrm{H}-7)$ and $\delta_{\mathrm{H}} 7.45(d d$, $J=7.5,8.5 \mathrm{~Hz}, 1 \mathrm{H}, \mathrm{H}-6)$. Altogether these signals suggest that $\mathbf{4}$ presented a trisubstituted aromatic ring. The gCOSY cross-peaks of the doublet at $\delta_{\mathrm{H}}$ $1.51(d, J=6.5 \mathrm{~Hz}, 3 \mathrm{H}, \mathrm{H}-9)$ coupled to a methine hydrogen atom with a signal at $\delta_{\mathrm{H}} 4.63(d q, J=$ $6.5,2.0 \mathrm{~Hz}, 1 \mathrm{H}, \mathrm{H}-3$ ) in turn coupled to a methine hydrogen atom at $\delta_{\mathrm{H}} 4.50(d, J=2.0 \mathrm{~Hz}, 1 \mathrm{H}, \mathrm{H}-4)$, suggesting an $\alpha$-methylhydroxy unit in the molecular structure of 4 . The broad singlet at $\delta_{\mathrm{H}} 11.0$ $(1 \mathrm{H})$ indicated the presence of an intramolecular hydrogen bond between a hydroxy group $(8-\mathrm{OH})$ and a carbonyl group (C-1). The ${ }^{13} \mathrm{C}$ NMR and DEPT $135^{\circ}$ spectra showed the presence of ten signals, assigned to one methyl $\left[\delta_{\mathrm{C}} 16.0(\mathrm{C}-9)\right]$, five methine groups $\left[\delta_{\mathrm{C}} 78.1(\mathrm{C}-3), \delta_{\mathrm{C}} 67.2(\mathrm{C}-4), \delta_{\mathrm{C}}\right.$ $\left.118.5(\mathrm{C}-5), \delta_{\mathrm{C}} 136.7(\mathrm{C}-6), \delta_{\mathrm{C}} 118.2(\mathrm{C}-7)\right]$, and three aromatic quaternary carbon atoms $\left[\delta_{\mathrm{C}} 162.1\right.$ $\left.(\mathrm{C}-8), \delta_{\mathrm{C}} 106.8(\mathrm{C}-8 \mathrm{a}), \delta_{\mathrm{C}} 140.5(\mathrm{C}-4 \mathrm{a})\right]$, and one signal at $\delta_{\mathrm{C}} 169.1(\mathrm{C}-1)$, which was attributed to a carbonyl group, suggesting that $\mathbf{4}$ is an dihydroisocoumarin. This information coupled to data of the literature (Holler et al., 1999) assigne 4 to the structure of 4-hydroxymellein.

Compound $\mathbf{5}$ was isolated as a white amorphous solid and its ESI mass data suggested the molecular formula $\mathrm{C}_{11} \mathrm{H}_{12} \mathrm{O}_{3}\left([\mathrm{M}+\mathrm{H}]^{+}\right.$at $\mathrm{m} / z$, 193). In particular, a high similarity between the NMR spectral data of compounds 5 and $\mathbf{4}$ was observed. The major difference was identified in the chemi- cal shifts attributed to $\mathrm{H}-4$ of $\mathbf{5}$, which showed a multiplet at $\delta_{\mathrm{H}} 2.80(2 \mathrm{H}, \mathrm{H}-4)$. Furthermore, the presence of a singlet at $\delta_{\mathrm{H}} 3.88(3 \mathrm{H}, \mathrm{H}-10)$ suggested a methoxy substituent. A $g \mathrm{HMBC}$ correlation was observed between the signal at $\delta_{\mathrm{C}} 161.2$ (C-8) and $\mathrm{H}-10$, which confirmed the position of the methoxy group at C-8. This information coupled to literature data (Kamisuki, 2007) assigne 5 to the structure of 8-methoxymellein.

The dihydroisocoumarin $\mathbf{6}$ was isolated as a white amorphous solid and its ESI mass data indicated the molecular formula $\mathrm{C}_{10} \mathrm{H}_{10} \mathrm{O}_{4}\left([\mathrm{M}-\mathrm{H}]^{-}\right.$ at $m / z$ 193). Considering differences in the NMR spectral data between compounds 5 and 6 , the ${ }^{1} \mathrm{H}$ NMR spectrum of $\mathbf{6}$ exhibited two ortho-coupled hydrogen atoms at $\delta_{\mathrm{H}} 6.73(d, J=9.0 \mathrm{~Hz}, 1 \mathrm{H}, \mathrm{H}-7)$ and $\delta_{\mathrm{H}} 6.92(d, J=9.0 \mathrm{~Hz}, 1 \mathrm{H}, \mathrm{H}-6)$, suggesting a tetrasubstituted aromatic ring. The ${ }^{13} \mathrm{C}$ NMR and DEPT $135^{\circ}$ data indicated signals at $\delta_{\mathrm{C}} 156.5$ and $\delta_{\mathrm{C}} 143.0$, which where attributed to the hydroxylated aromatic carbon atoms C-8 and C-5, respectively. These data indicate a hydroquinone ring in the molecular structure of $\mathbf{6}$, which was identified as 5-hydroxymellein (Harwood, 1984).

Compounds 1-6 were evaluated for their antifungal activity against Cladosporium cladosporioides and $C$. sphaerospermum using a direct bioautography assay (Table I). The most active compounds, orcinol (1) and 4-hydroxymellein (4), showed a potent effect towards the yeasts, exhibiting a detection limit of 5.00 and $10.0 \mu \mathrm{g}$ against C. cladosporioides and C. sphaerospermum, respectively. 5 exhibited moderate fungitoxicity towards C.cladosporioides and C. sphaerospermum, showing a detection limit of 10.0 and $25.0 \mu \mathrm{g}$, re-

Table I. Antifungal and acetylcholinesterase inhibitory activities of compounds $\mathbf{1}-\mathbf{6}$.

\begin{tabular}{|c|c|c|c|}
\hline \multirow[t]{2}{*}{ Compound } & \multicolumn{2}{|c|}{ Antifungal activity ${ }^{a}$} & \multirow{2}{*}{$\begin{array}{l}\text { Acetylcholinesterase } \\
\text { inhibitory activity }^{\mathrm{a}}\end{array}$} \\
\hline & $\begin{array}{l}\text { Cladosporium } \\
\text { cladosporioides }\end{array}$ & $\begin{array}{c}\text { Cladosporium } \\
\text { sphaerospermum }\end{array}$ & \\
\hline $\mathbf{1}$ & 5.00 & 10.0 & 60.0 \\
\hline 2 & 50.0 & 50.0 & 10.0 \\
\hline$\overline{3}$ & 25.0 & 25.0 & 60.0 \\
\hline 4 & 5.00 & 10.0 & 30.0 \\
\hline 5 & 10.0 & 25.0 & $>100$ \\
\hline 6 & 50.0 & 50.0 & $>100$ \\
\hline Nystatin ${ }^{\mathrm{b}}$ & 1.00 & 1.00 & - \\
\hline Galanthamine $e^{c}$ & - & - & 1.00 \\
\hline
\end{tabular}

Expressed as minimum amount required for inhibition of fungal growth on TLC plates (in $\mu \mathrm{g}$ ).

b Positive control employed for antifungal activity assay.

c Anti-Alzheimer's drug and positive control adopted for acetylcholinesterase inhibitory activity test. 
spectively. 5-Hydroxymellein (6) proved to be not potent, since the content at which this compound showed activity was $50 \mu \mathrm{g}$. Altogether, these data indicate a clear positive correlation between the antifungal effect demonstrated by the dihydroisocoumarins and free hydroxy groups at C-4 and C-8. The identification of the compounds 1,4 and $\mathbf{5}$, potentially bioactive against the phytopathogenic fungi, indicates that they act as defence of the host species against possible attacks of pathogens.

Although a broad spectrum of antimicrobial activities has already been demonstrated for compounds isolated from Penicillium, few studies have been devoted to the acetylcholinesterase (AChE) inhibitory activity. AChE catalyzes the hydrolysis of acetylcholine to terminate the impulse-transmitted action through cholinergic synapses (Stryer, 1995; Sigurdsson and Gudbjarnason, 2007). Although the fundamental reason of Alzheimer's disease (AD) is not clear so far, $\mathrm{AD}$ is firmly associated with impairment in the cholinergic transmission. A number of AChE inhibitors have been considered as candidates for the symptomatic treatment of $\mathrm{AD}$ as the most useful relieving strategy (Barbosa-Filho et al., 2006; Alarcón et al., 2008). The diketopiperazine 2 exhibited the highest AChE inhibitory activity displaying a detection limit of $10.0 \mu \mathrm{g}$ (Table I). Compounds $\mathbf{1}$ and $\mathbf{3}$ showed a detection limit of

Alarcón J., Astudillo L., and Gutierrez M. (2008), Inhibition of acetylcholinesterase activity by dihydro$\beta$-agarofuran sesquiterpenes isolated from Chilean Celastraceae. Z. Naturforsch. 63c, 853-856.

Barbosa-Filho J. M., Medeiros K. C. P., Diniz M. F. F. M., Batista L. M., Athayde-Filho P. F., Silva M. S., Cunha E. M. V., Almeida J. R. G. S., and Quintans-Junior L. J. (2006), Natural products inhibitors of the enzyme acetylcholinesterase. Braz. J. Pharmacogn. 16, $258-285$.

Bolzani V. S., Trevisan M. V. L., and Young M. C. M. (1991), Caffeic acid esters and triterpenes of Alibertia macrophylla. Phytochemistry 30, 2089-2091.

Cafêu M. C., Silva G. H., Teles H. L., Bolzani V. S., Araújo A. R., Young M. C. M., and Pfenning L. H. (2005), Substâncias antifúngicas de Xylaria sp., um fungo endofítico isolado de Palicourea marcgravii (Rubiaceae). Quim. Nova 28, 991-995.

Fill T. P., Pereira G. K., Santos R. M. G., and RodriguesFilho E. (2007), Four additional meroterpenes produced by Penicillium sp. found in association with Melia azedarach. Possible biosynthetic intermediates to austin. Z. Naturforsch. 62b, 1035-1044.
$60 \mu \mathrm{g}$, which was considered as weakly potent. The dihydroisocoumarin 4 displayed moderate AChE inhibitory activity, exhibiting a detection limit of $30.0 \mu \mathrm{g}$. On the other hand, compounds 5 and $\mathbf{6}$ were not active (detection limits over $100 \mu \mathrm{g}$ ). Similar to the observed antifungal activity, free hydroxy groups at C-4 and C- 8 corroborate to increase the anti-AChE potency presented by dihydroisocoumarins.

In conclusion, six metabolites from Penicillium sp.1 and Penicillium sp.2, two endophytes associated with $A$. macrophylla leaves, exhibited potential bioactivity, including antifungal and $\mathrm{AChE}$ inhibitory activities. The results suggest that compounds 2 and 4 should be considered further in the development of new agrochemicals and/or hit compounds for the use in the drug design for Alzheimer's disease treatment.

\section{Acknowledgements}

This work was funded by grants of the Fundação de Amparo à Pesquisa do Estado de São Paulo (FAPESP) as part of Biota-FAPESP, The Biodiversity Virtual Institute Program (www.biota.org.br), grant no. 03/02176-7, awarded to V. S. B.; C. M. O. and L. O. R. acknowledge FAPESP and L. M. Z. acknowledges Coordenação de Aperfeiçoamento de Pessoal de Nível Superior (CAPES) for MS and Ph.D. scholarships.

Furtado N. A. J. C., Pupo M. T., Carvalho I., Campo V. L., Duarte M. C. T., and Bastos J. K. (2005), Diketopiperazines produced by an Aspergillus fumigatus strain. J. Braz. Chem. Soc. 16, 1448-1453.

Harwood L. M. (1984), Access to phenolic fungal metabolites via the acid-catalysed Claisen rearrangement. The total synthesis of (+)-mellein, aurocitrin, and 5',6'-dihydroaurocitrin. J. Chem. Soc. Perkin Trans. 1, 2577-2582.

Holler U., Konig G. M., and Wright A. D. (1999), Three new metabolites from marine-derived fungi of the genera Coniothyrium and Microsphaeropsis. J. Nat. Prod. 62, 114-118.

Hormazabal E., Schmeda-Hirschmann G., Astudillo L., Rodriguez J., and Theoduluz C. (2005), Metabolites from Microsphaeropsis olivacea, an endophytic fungus of Pilgerodendron uviferum. Z. Naturforsch. 60c, $11-21$.

Inácio M. L., Silva G. H., Teles H. L., Trevisan H. C., Cavalheiro A. J., Bolzani V. S., Young M. C. M., Pfenning L. H., and Araújo A. R. (2006), Antifungal metabolites from Colletotrichum gloeosporioides, an endophytic fungus in Cryptocarya mandioccana Nees (Lauraceae). Biochem. Syst. Ecol. 34, 822-824. 
Kamisuki S. (2007), Nodulisporol and nodulisporone, novel specific inhibitors of human DNA polymerase $\mathrm{k}$ from a fungus, Nodulisporium sp. Bioorg. Med. Chem. 15, 3109-3114.

Marston A., Kissling J., and Hostettmann K. (2002), A rapid TLC bioautographic method for the detection of acetylcholinesterase and butyrylcholinesterase inhibitors in plants. Phytochem. Anal. 13, 51-54.

Martin F. P. J., Wang Y., Sprenger N., Holmes E., Lindon J. C., Kochhar S., and Nicholson K. (2007), Effects of probiotic Lactobacillus paracasei treatment on the host gut tissue metabolic profiles probed via magicangle-spining NMR spectroscopy. J. Proteome Res. 6, $1471-1481$.

Monde K. (1998), Organochlorine compounds from a terrestrial higher plant: structures and origin of chlorinated orcinol derivatives from diseased bulbs of Lilium maximowiczii. J. Nat. Prod. 61, 913-921.

Raeder J. and Broda P. (1985), Rapid preparation of DNA from filamentous fungi. Lett. Appl. Microbiol. 1, $17-20$.

Rahalison L., Hamburger M., Hostettmann K., Monod M., and Frenk E. (1991), A bioautographic agar overlay method for the detection of anti-fungal compounds from higher plants. Phytochem. Anal. 2, 199-201.

Schindler M. (1998), Magnetic properties in terms of localized quantities. The DNA bases and the protonation of adenine. J. Am. Chem. Soc. 110, 6623-6630.

Schmeda-Hirschmann G., Hormazabal E., Rodriguez J. A., and Theoduloz C. (2008), Cycloaspeptide A and pseurotin A from the endophytic fungus Penicillium janczewskii. Z. Naturforsch. 63c, 383-388.
Sigurdsson S. and Gudbjarnason G. (2007), Inhibition of acetylcholinesterase by extracts and constituents from Angelica archangelica and Geranium sylvaticum. Z. Naturforsch. 62c, 689-693.

Silva G. H., Teles H. L., Zanardi L. M., Young M. C. M., Eberlin M. N., Haddad R., Pfenning L. H., CostaNeto C., Castro-Gamboa I., Bolzani V. S., and Araújo A. R. (2006), Cadinane sesquiterpenoids of Phomopsis cassiae, an endophytic fungus associated with Cassia spectabilis (Leguminosae). Phytochemistry 67, 1964-1969.

Silva V. C., Faria A. O., Bolzani V. S., and Lopes M. N. (2007), A new ent-kaurane diterpene from stems of Alibertia macrophylla K. Schum. (Rubiaceae). Helv. Chim. Acta 90, 1781-1785.

Singh S. B. (2003), Isolation, structure, and HIV-1 integrase inhibitory activity of xanthoviridicatin $\mathrm{E}$ and F, two novel fungal metabolites produced by Penicillium chrysogenum. Helv. Chim. Acta 86, 3380-3385.

Stierle A. A., Stierle D. B., and Kelly K. (2006), Berkelic acid, a novel spiroketal with selective anticancer activity from an acid mine waste fungal extremophile. J. Org. Chem. 71, 5357-5360.

Stryer L. (1995), Biochemistry, 4th ed. Freeman, San Francisco, p. 1017.

Takahashi J. A. and Lucas E. M. A. (2008), Ocorrência e diversidade estrutural de metabólitos fúngicos com atividade antibiótica. Quim. Nova 31, 1807-1813.

Teles H. L., Sordi R., Silva G. H., Castro-Gamboa I., Bolzani V. S., Pfenning L. H., Abreu L. M., CostaNeto C. M., Young M. C. M., and Araújo A. R. (2006), Aromatic compounds produced by Periconia atropurpurea, an endophytic fungus associated with $X y$ lopia aromatica. Phytochemistry 67, 2686-2690. 